\title{
LIST OF TABLES, MAPS AND FIGURES
}

\section{TABLES}

3.1: Two Streams of Environmentalism in Hong Kong 103

7.1: Environmental Background of a Selection of 208

Elected Representatives after Malaysia's 14th General

Election (2018)

10.1: Chinese Involvement in Cambodian Hydropower

Development

11.1: Democracy Rankings

11.2: Environmental Rankings $\quad 345$

11.3: Environmental Performance and Political Regime 348

\section{MAPS}

1.1: Taiwan, Hong Kong, and the capital cities of the Southeast 21 Asian countries studied in this book

2.1: Selected sites of environmental disputes in Taiwan 50

3.1: Selected sites of environmental disputes in Hong Kong 83

4.1: Selected sites of environmental disputes in Singapore 112

5.1: Selected sites of environmental disputes in the Philippines 145

6.1: Selected sites of environmental disputes in Indonesia 180

7.1: Selected sites of environmental disputes in Malaysia 213

8.1: Selected sites of environmental disputes in Thailand 244

9.1: Selected sites of environmental disputes in Vietnam 280

10.1: Dam projects with Chinese participation in Cambodia 312 
All maps are made by Gordon Shih-hao Jheng, with QGIS software, a free and open source Geographic Information System (www.qgis. org/en/site), and complementary data from Natural Earth, a public domain map dataset (www.naturalearthdata.com).

\section{FIGURES}

2.1: The three composing spheres of civic eco-nationalism: nationalism, ecology, and democratic spirit

2.2: Demonstration against air pollution in the shape of Taiwan with the banner "One Sky, but two Taiwans", in Taichung, 19 February 2017

2.3-2.4: Demonstration against air pollution in Taichung, 19 February 2017

2.5: $\quad$ PM2.5 in Taiwan, 2009-18

2.6: Demonstration against Asia Cement in the shape of Taiwan, Taipei, 25 June 2017

2.7: $\quad$ Press conference in front of Formosa Plastics' annual shareholders' meeting in Taipei, on the day the lawsuit was launched at the Taipei District Court, 11 June 2019

3.1: $\quad$ Members of the Land Justice League and the League of Social Democrats protesting against the construction of the Guangzhou-Shenzhen-Hong Kong Express Railway Link, 19 March 2016

4.1: $\quad$ A long-tailed macaque with her baby at the fringe of Bukit Timah Nature Reserve, Singapore

4.2: Macaques feeding by the roadside in the western part of Singapore, 2012

4.3: $\quad$ Students, monks, and environmental activists gather hand in hand with the local community, in chesthigh water to bless and protect the mangrove forests at Lovers' Island (Kaoh Bang โกาะ ชพฉ and Kaoh Aun โกาะ รูฐ Province, Southwest Cambodia 
4.4: $\quad$ Phalla Vy stands before mountains of sand piled at a storage facility in Singapore, discovering for the first time what happened to the sand that was dredged up and seized from her homeland of Koh Sralau, Koh Kong Province, Southwestern Cambodia

5.1: Catholic nuns participating in the march for climate justice in Manila, November 2015

7.1-7.2: A protest against Lynas supported by many civil society organizations, notably Himpunan Hijau, Bersih, and Indigenous groups at Gebeng, in the state of Pahang, 24 June 2012

8.1: Triangulated dynamism between the government, NGOs, and citizens

8.2: $\quad$ Thai police officers captured university students and activists during their protest against the construction of the Mae Wong Dam at Kasetsart University, Bangkok, 18 November 2014

9.1: $\quad$ A protest near the entrance of Formosa Ha Tinh Steel, Ký Anh, 4 October 2016

9.2: $\quad$ Fishermen on the beach near Formosa Ha Tinh Steel, Ký Anh, 4 February 2018

10.1: $\quad$ The venerable But Buntenh leads a group of monks from the Independent Monk Network for Social Justice as they travel from the capital city of Phnom Penh to support the people of Areng Valley in their protest against the construction of a hydroelectric dam in Southwestern Cambodia

10.2: But Buntenh and his fellow monks from the Network for Social Justice perform a tree ordination ceremony as part of the effort to prevent the construction of the Areng Valley hydroelectric dam in Southwestern Cambodia 